\title{
My Bakhtin: A reply to the commentaries
}

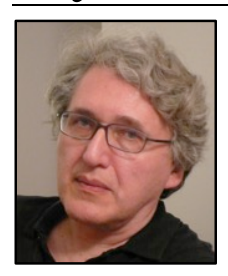

Boris Groys

New York University, USA

First of all, I am grateful to Eugene Matusov for organizing this forum. And I am grateful to the participants for their analysis of my text. Especially, I am grateful to Caryl Emerson who summarized this forum in such a clear and elegant manner that for a moment I thought that I just should refer to her text instead of writing anything in response.

However, I decided to say something after all. Some respondents did not limit their responses to the analysis of my text but questioned the motives that moved me to write this text. The explanations of these motives go from the pseudo-elitist hate of the simple people to the evil envy of the true elites (of Bakhtin in this case). Of course, I am not in a position to question these deep psychological insights. Instead, I will present my own, purely subjective and unscientific memories of my state of mind as I wrote the Bakhtin essay.

The goal of this text was not to criticize or to denigrate Bakhtin. On the contrary, the goal was to write a complimentary text praising Bakhtin. Particularly, I wanted to praise Bakhtin for three things that he has done.

1. I agree with Hegel that the highest achievement of the thinking is to grasp one's own time. So, I wanted to show that Bakhtin's text is not simply another book on carnival or Rabelais but an attempt to achieve more: to grasp its own time, the Stalinist culture in the middle of which he was living. It would be wrong to see the Stalinist culture as an absolutist (Apollonian) order. This culture wanted to achieve a unity between order and chaos - otherwise it would not be totalistic or, let say, totalitarian. This is characteristic for all the modern totalitarian projects. Thus, Hannah Arendt shows very well in her book on the totalitarianism that the Hitler regime permanently negated and deconstructed its own order. The same we could see in the case of the Chinese cultural revolution that also took very obvious carnivalistic character. Bakhtin saw that very early - more or less at the same time as Roger Caillois and Georges Bataille. That is why I tried to draw the attention of the reader to this Bakhtin's achievement.

2. In a time I wrote this text the Cold War was - at least ideologically - not at the end. One could be only for the Soviets or against them, loyalist or dissident etc. It always seemed to me that to simply reject the Soviet power does not mean to transcend it because a possibility of such a rejection was already included in the Soviet ideology (that had a place for the anti-communism in its own world view.) So for me to transcend the Soviet ideology meant to transcend the whole system of oppositions by which this ideology operated. Now in my view Bakhtin made precisely that. So, I proposed his thinking as a model for my own thinking - and also thinking of my friends.

3. Bakhtin's text belongs in a great tradition of the Gesamtkunstwerk. Every Gesamtkunstwerk is 
an effect of secularization of the Christian church - Pavel Florensky wrote already about it. The Bakhtinian "polyphonic novel" describes the society dominated by the class division (as it was the case during the Soviet 1920s) and the carnival book describes the classless society of the people (narod) as it was proclaimed by Stalin in the 1930s. In both cases Bakhtin applies christological dogmat on the figure of the author: the author has one personality but two essences - he is in the heaven above the earth (as God-Father) and suffers on earth (as GodSon). The 1930s was a time of the political theology that tried to find in the theological tradition the genealogy of the secular political notions and categories (Carl Schmitt, Walter Benjamin). I find that Bakhtin made a very deep and original contribution to the political theology too because the figures of author and authority are genuinely modern political figures.

And now the last point. In the text itself and now in my explanations of it I permanently go back to the 1930s. So, a question may arise: does the Bakhtinian theory remain valid for our own time? I think yes - because the modern condition has not changed so radically. It is enough to look at the Internet which is the best example of Bakhtinian totalistic and carnevalistic unity between order and disorder.

\section{(c) E EY}

New articles in this journal are licensed under a Creative Commons Attribution 4.0 United States License.

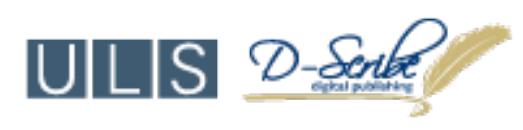

This journal is published by the University Library System, University of Pittsburgh as part of its D-Scribe Digital Publishing Program and is cosponsored by the University of Pittsburgh Press. 